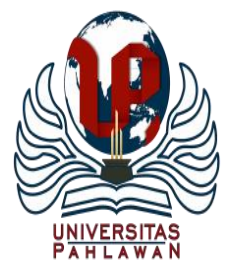

Edukatif : Jurnal Ilmu Pendidikan Volume 3 Nomor 4 Tahun 2021 Halm 1120 - 1132 EDUKATIF: JURNAL ILMU PENDIDIKAN

Research \& Learning in Education

https://edukatif.org/index.php/edukatif/index

\title{
Impelementasi Asas-asas Pengembangan Kurikulum terhadap Pengembangan Kurikulum Pendidikan Agama Islam
}

\author{
Satria Kharimul Qolbi ${ }^{1 凶}$, Tasman Hamami ${ }^{2}$ \\ Universitas Islam Negeri Sunan Kalijaga Yogyakarta, Indonesia ${ }^{1,2}$ \\ E-mail : kafacila@gmail.com ${ }^{1}, \underline{\text { tasmanhamami61@ gmail.com }}^{2}$
}

\begin{abstract}
Abstrak
Setiap masa terdapat perubahan-perubahan yang signifikan dalam dunia pendidikan agama Islam, sehingga pada prosesnya membutuhkan suatu rangkaian pengembangan kurikulum yang tepat dengan pondasi yang kuat agar arah tujuan pengembangannya jelas, maka dari itu diperlukannya asas-asas yang tepat untuk diterapkan dalam pengembangan kurikulum pendidikan agama Islam. Penulisan ini bertujuan bagaimana kontribusi asas-asas pengembangan kurikulum diterapkan pada pengembangan kurikulum pendidikan agama Islam. Metode penulisan ini menggunakan kajian studi kepustakaan mengelola data dengan analisis deskriptif disajikan secara sistematis dan objektif. Dari hasil penelitian terdapat lima asas yang diterapkan pada pengembangan kurikulum PAI. Asas-asas tersebut antara lain asas teologi, asas, filosofis, asas psikologi, asas sosial-budaya, asas ilmu pengetahuan dan teknologi. Penerapan kelima asas tersebut antara lain asas teologi menggunakan Al-Qur'an dan Hadits, asas filosofis menggunakan perpaduan konsep aliran filsafat, asas psikologi menentukan kemampuan sesuai jenjang, asas sosial-budaya menekankan pengenalan budaya, serta asas ilmu pengetahuan dan teknologi memaksimalkan pengembangan tekonologi terhadap kegiatan pembelajaran. Kesimpulan dari penelitian ini bahwa implementasi asas-asas pengembangan kurikulum berkontribusi terhadap pengembangan kurikulum pendidikan agama Islam secara teoritis maupun praktis dapat menjadi pelengkap bagi pihak-pihak berwenang dalam menyusun keputusan tentang kurikulum pendidikan agama Islam.
\end{abstract}

Kata Kunci: Asas, Pengembangan Kurikulum, Pendidikan Agama Islam.

\begin{abstract}
Every time there are significant changes in the world of Islamic religious education, so that in the process it requires a series of appropriate curriculum development with a strong foundation so that the direction of its development goals is clear, therefore the right principles are needed to be applied in the development of the religious education curriculum. Islam. This writing aims at how the contribution of the principles of curriculum development is applied to the development of the Islamic religious education curriculum. This writing method uses literature study to manage data with descriptive analysis presented systematically and objectively. From the research results, there are five principles that are applied to the development of the Islamic Education curriculum. These principles include theological principles, philosophical principles, psychological principles, social-cultural principles, science and technology principles. The application of these five principles includes the principle of theology using the Al-Qur'an and Hadith, the philosophical principle of using a combination of philosophical school concepts, the principle of psychology determining abilities according to levels, the socio-cultural principle emphasizing the introduction of culture, and the principle of science and technology maximizing the development of technology towards Learning Activities. The conclusion of this study is that the implementation of the principles of curriculum development contributes to the development of the Islamic religious education curriculum theoretically and practically can be a complement to the authorities in making decisions about the Islamic religious education curriculum.
\end{abstract}

Keywords: Principles of Curriculum Development, Islamic Religious Education.

Copyright (c) 2021 Satria Kharimul Qolbi, Tasman Hamami

$\triangle$ Corresponding author

Email : kafacila@gmail.com

DOI : https://doi.org/10.31004/edukatif.v3i4.511

ISSN 2656-8063 (Media Cetak)

ISSN 2656-8071 (Media Online)

Edukatif : Jurnal Ilmu Pendidikan Vol 3 No 4 Tahun 2021 p-ISSN 2656-8063 e-ISSN 2656-8071 
1121 Impelementasi Asas-asas Pengembangan Kurikulum terhadap Pengembangan Kurikulum Pendidikan Agama Islam - Satria Kharimul Qolbi, Tasman Hamami

DOI: https://doi.org/10.31004/edukatif.v3i4.511

\section{PENDAHULUAN}

Pendidikan secara fungsional memiliki peran besar dalam transformasi kehidupan manusia. Merujuk sejarah manusia tentunya dapat dilihat perubahan-perubahan yang terjadi pada manusia khususnya meningkatnya ilmu pengetahuan. Potensi manusia berupa akal sehat digunakan untuk berfikir, bernalar dan menganalisa suatu permasalahan hidup tentunya membuat manusia untuk menemukan suatu solusi yang tepat dalam meyelesaikan permasalahannya. Hal tersebut merupakan bentuk nyata akal manusia dalam memiliki ilmu pengetahuan seiring berjalannya waktu manusia memiliki mekanisme yang tepat dalam mentrasfer ilmu dari sesemanusia yang dijadikan rujukan ilmu kepada khalayak umum yaitu dengan sistem pendidikan. Pendidikan berarti bimbingan manusia dewasa kepada anak-anak, manusia yang lebih tua kepada yang lebih muda dan sebaliknya untuk dapat memberikan pengarahan, pengajaran, perbaikan moral dan melatih intelektual sesemanusia (Nurhalita, 2021).

Pendidikan pada dasarnya memiliki cakupan makna yang luas, merujuk kbbi.kemdikbud.go.id pendidikan berupa proses sikap tata laku permanusiaan atau kelompok yang dirubah dengan usaha pengajaran dan pelatihan. Pendidikan juga merupakan usaha sadar yang terencana untuk menciptakan suasana belajar yang menarik dengan proses pembelajaran yang baik agar peserta didik dapat mengembangkan potensi dirinya serta memiliki kekuatan spiritual keagamaan, pengendalian diri, kepribadian, kecerdasan, akhlak mulia, serta keterampilan yang diperlukan bagi dirinya, masyarakat, bangsa dan Negara (Sanjaya, 2010). Poin penting dari pendidikan disini adalaha adanya proses pengajaran, pelatihan dan pembelajaran dari sesemanusia yang menjadi rujukan ilmu seperti guru, dosen, atau ulama dalam bidang agama kepada khalayak umum yang membutuhkan pengembangan pengetahuan seperti peserta didik atau manusia pada umumnya sehingga tujuan pendidikan membentuk manusia yang berilmu, memiliki kekuatan spiritual keagamaan, pengendalian diri, kepribadian, kecerdasan, akhlak mulia, serta keterampilan tercapai dengan baik. Pencapaian ini tentunya tidak mudah perlu adanya konsep rangkaian yang tepat agar proses pendidikan terlaksana secara sistematis dan terstruktur yaitu dengan menggunakan kurikulum.

Undang-undang Nomor 20 tahun 2003 itu kurikulum terdiri dari seperangkat rencana, peraturan mengenai isi, bahan pelajaran serta cara yang tepat sebagai pedoman dalam pelaksanaan proses belajar mengajar. Pada kurikulum terdapat seperangkat rencana pembelajaran, isi materi, bahan serta proses pembelajaran hal tersebut bagian terpenting dalam tujuan pendidikan. Kurikulum juga mengatur model-model evaluasi dalam menentukan tolok ukur hasil keberhasilan belajar peserta didik. Kurikulum mengatur standar yang tepat dalam memberikan penilaian bagi pendidik maupun peserta didik. Sehingga dengan kurikulum maka pendidikan berlangsung secara teratur dan terstruktur. Dalam mewujudkan kurikulum tersebut maka perlu ditelaah lebih lanjut bagaiaman menentukan kurikulum yang tepat untuk digunakan pada satuan pendidikan sehingga diperlukannya pengembangan dalam kurikulum. Seiring berjalannya waktu kebutuhan manusia akan pengetahuan akan berkembang dan berubah sertahal yang sangat tampak adalah perkembangan teknologi. Hal tersebut sangat mempengaruhi perkembangan kurikulum, maka dalam pengembangannya perlu adanya landasan atau asas yang tepat sebagai pondasi bagi pengembangan kurikulum.

Asas kurikulum menjadikan landasan bagaiamana kurikulum tersebut dibuat, disusun serta dikembangankan. Dalam pengembangannya asas-asas menuntun kurikulum agar dapat berkembang sesuai prinsip-prinsip pendidikan yang dibutuhkan. Dengan adanya asas ini kurikulum memiliki pondasi yang kuat baik itu kurikulum pada pendidikan umum maupun pendidikan agama Islam. Pendidikan agama Islam memiliki visi misi yang idel yaitu Rohmatan lil A'lamin dan konsep dasar pendidikan Islam lebih mendalam menyangkut persoalan hidup multi dimensional yaitu pendidikan yang tidak terpisah dari tugas kekhalifahan manusia atau sebagai kader khalifah dalam rangka membangun kehidupan dunia yang makmur, dinamis, harmonis dan lestari sebagaimana diisyaratkan Allah dalam Al-Qur'an (Rahmat Hidayat, 2016). 


\section{Impelementasi Asas-asas Pengembangan Kurikulum terhadap Pengembangan Kurikulum Pendidikan}

Agama Islam - Satria Kharimul Qolbi, Tasman Hamami

DOI: https://doi.org/10.31004/edukatif.v3i4.511

Fakta bahwa dari masa ke masa terdapat perubahan transformasi baik dari segi kebutuhan pokok, dari permasalahan agama maupun permasalahan pendidikan. tentu pendidikan pada masa lampau berbeda permasalahannya pada masa sekarang baik itu pendidikan secara umum maupun pendidikan agama Islam, maka dari itu perlunya pengembangan dalam suatu pendidikan agama Islam agar dapat beradaptasi dengan perkembangan zaman sehingga diperlukannya suatu pondasi pengembangan kurikulum pendidikan tetap memiliki prinsip yang kuat. Untuk meninjau hal tersebut maka diperlukannya teori-teori yang membahas asasasas pengembangan kurikulum pendidikan sehigga dapat diimplementasikan terhadap pengembangan kurikulum pendidikan agama Islam dengan tujuan untuk mengetahui seberapa besar kotribusi asas-asas tersebut terhadap pengembangan kurikulum PAI.

Peneliti meninjau karya Abdul Halim dalam jurnalnya Asas-asas Pengembangan Kurikulum Pendidikan Islam Multikultur berangkat dari permasalah globalisasi yang berdampak hilangnya skat antar perbedaan tradisi budaya dan masyarakat sehingga perlu adanya pengelolahan yang tepat agar tidak terjadi benturan dalam perbedaan tersebut. Peran pendidikan agama Islam sangat signifikan dalam menebar ajaran nilai-nilai multikultural seperti toleransi, demokrasi, moderat dan menghargai sehingga dengan adanya globalisasi ini banyak terdapat perubahan-perubahan dalam pendidikan agama Islam. Menanggapai hal ini perlu adanya pengembangan kurikulum pendidikan agama Islam multikultur. Berbicara pengembangan tentu terdapat dasar-dasar atau asas yang kuat dalam pengembangan tersebut. Dalam penelitian ini terdapat empat asas yaitu asas teologis, asas filosofis, asas yuridis dan asas sosiologis yang menjadi dasar pengembangan kurikulum pendidikan agama Islam Multikulturan. Fokus penelitian tersebut perubahan yang ada pada masyarakat multikultur sehingga diperlukannya asas pengembangan kurikulum pendidikan agama Islam agar menghasilkan sebuah pendidikan Islam multikultur yang dapat diimplementasikan dalam pembelajaran pendidikan Agama Islam(Halim, 2016). Peneliti juga mengaitkan penulisan ini dengan Keputusan Menteri Agama Nomor 183 Tahun 2019 tentang Kurikulum PAI dan Bahasa Arab pada Madrasah karena wujud dari pengembangan kurikulum PAI dari keputusan tersebut.

Dari kajian penelitian Abdul Halim tersebut peneliti ingin mengembangkan penelitian mengenai Implemetasi asas-asas pengembangan kurikulum terhadap pengembangan kurikulum pendidikan agama Islam. Persamaan dalam penelitian ini yaitu membahas tentang asas-asas pengembangan kurikulum pendidikan agama Islam. Perbedaannya terdapat pada fokus pembahasan, Abdul Halim membahas asas-asas pengembangan kurikulum dalam perubahan globalisasi sehingga terciptanya pendidikan agama Islam Multikutur, sedangkan peneliti membahas implementasi dari asas-asas pengembangan kurikulum terhadap pengembangan kurikulum pendidikan agama Islam.

\section{METODE}

Penulisan ini membahas tentang asas-asas dalam pengembangan kurikulum dalam pendidikan agama Islam. Menggunakan metode studi kepustakaan dengan mencari data-data yang berasal dari buku dan artikel ilmiah yang terdapat relevansi mengenai topik pembahasan. Selanjutnya mengelola data dengan analisis deskriptif yang penulis sajikan secara sistematis dan objektif (Mustika, 2008). Data diperoleh melalui dokumentasi, yaitu menggali data menurut aneka macam warta jurnal, buku, serta informasi-informasi lain.

Proses selanjutnya penulis menelaah dari beberapa jurnal, artikel, makalah dan buku serta sumber yang sesuai dengan peulisan ini. Penulisan ini penelusurannya dilakukan secara literatur. Linteratur sebagai kajian pustaka agar menemukan data teori yang berkaitan dengan implementasi Asas-asas pengembangan kurikulum terhadap pengembangan kurikulum pendidikan agama Islam dan data dianalasis secara sistematis serta disimpulkan secara objektif 
1123 Impelementasi Asas-asas Pengembangan Kurikulum terhadap Pengembangan Kurikulum Pendidikan Agama Islam - Satria Kharimul Qolbi, Tasman Hamami

DOI: https://doi.org/10.31004/edukatif.v3i4.511

\section{HASIL DAN PEMBAHASAN}

Asas adalah sesuatu hal yang bersifat fundamental berkaitan dengan pemikiran tujuan dan hukum pokok dari sesuatu tindakan (Halim, 2016). Dapat menganalogikan suatu bangunan seperti rumah dan gedunggedung tinggi seperti diperkotaan besar. Sebelum terbentuknya suatu bangunan utuh tentunya akan dirangkai terlebih dahulu landasan tujuan agar bangunan tersebut tetap kokoh dari cuaca buruk angin kencang dan gempa sehingga dapat digunakan dengan baik. Dari analogi tersebut dapat memahami betapa besar pentingnya suatu asas, pondasi atau landasan. Kurikulum dalam pandangan klasik memiliki arti kumpulan seluruh mata pelajaran yang disampaikan pada peserta didik, namun beberapa pendapat menyatakan bahwa kurikulum rangkaian pengalaman terdiri dari ilmu sosial, pendidikan, kebudayaan, olahraga, serta ilmu kesenian yang berada pada setiap lembaga pendidikan guna mengembangkan setiap aspek pada peserta didik dalam mengubah tingkah lakunya yang lebih baik menyesuaikan tujuan pendidikan (Hermawan et al., 2020). Kurikulum sebagai sekumpulan mata pelajaran, tentu mata pelajaran tersebut harus dipelajari semua peserta didik sampai dengan hasil berbentuk nilai baik secara fisik maupun nonfisik seperti perilaku. Nilai tersebutlah yang akan dijadikan ukuran keberhasilan peserta didik yang dicantumkan pada sebuah Ijazah.

Dalam perkembangannya kurikulum memiliki makna yang lebih luas. Kurikulum dalam pendidikan modern jauh lebih holistic, komperhensif yang mencakup semua unsur pendidikan yaitu sangat berhubungan dengan semua rangkaian pendidikan (Irsad, 2016). Dalam jurnal Muhaamad Irsad, Menurut Ahmad Tafsir kurikulum tidak hanya sekedar rencana pembelajaran atau bidang studi tertentu, melainkan semua rangkain yang terjadi dalam proses pendidikan di sekolah. Menurut Hasan Langgunglung, Kurikulum adalah kumpulan yang terdiri dari pengalaman, pendidikan, kebudayaan, sosial olahraga dan kesenian di kelola di dalam kelas maupun di luar kelas (Irsad, 2016). Yeni menyatakan dalam jurnalnya bahwa menurut S. Nasution kurikulum secara defenisi dapat dibagi sebagai beriukut (Yeni Tri Nur Tahmawati, 2018):

1. Kurikulum sebagai sebuah produk yakni hasil karya dari pengembang kurikulum, biasanya dalam susunan panitia tersendiri yang bentuk produknya berupa buku pendoman kurikulum yang berisi mata pelajaran yang haru diajarkan.

2. Kurikulum sebagai program, yakni alat yang dilakukan oleh sekolah untuk mencapai tujuanya. Berupa kegiatan yang dapat mempengaruhi perkembangkangan potensi peserta didik, diantaranya perkumpulan sekolah, pertandingan antar sekolah dan pramuka. Cakupan dari kurikulum yang dapat dipelajari.

Dari berbagai pandangan diatas bahwa kurikulum merupakan rangkaian yang terdiri dari rancangan pembelajaran, mata pelajaran, proses pembelajaran keterampilan, sikap dan praktek serta panduan penilaian yang menjadi tolok ukur keberhasilan tercapainya nilai peserta didik sehingga nilai tersebut dapat menjadi hasil produk berupa rapot dan ijazah.

Kurikulum pendidikan agama Islam sendiri memiliki arti merancang materi agama Islam, tujuan dalam proses pembelajaran, metode strategis dan metode evaluasi. Dengan kata lain, kurikulum pendidikan agama Islam merupakan upaya sadar dan terencana yang dirancang untuk membantu siswa memahami, memahami, menghayati, meyakini dan mengamalkan seluruh ajaran Islam (Noorzanah, 2018). Kurikulum pendidikan agama Islam juga memuat materi pembelajaran yang berbasis pada pendidikan agama Islam, materi tersebut dimulai dari aktivitas, pengetahuan, kebiasaan, dan pengalaman terstruktur yang diberikan kepada peserta didik agar pendidikan agama Islam tercapai tujuannya dengan baik. Alat-alat tersebut dapat berupa materi pendidikan agama Islam, kegiatan-kegiatan Keislaman, program yang terstruktur dalam proses pembelajaran serta praktek-praktek pembelajaran yang dapat dijadikan pengamalan peserta didik untuk menjalankan perintah ajaran agama Islam dari komponen tersebut terdapat pula evaluasi sebagai tolok ukur seberapa besar keberhasilan peserta didik dalam menempuh pendidikan agama Islam.

Asas kurikulum adalah pemikiran yang memiliki landasan diijadikan suatu pondasi bagi kurikulum yang disusun dan dibentuk secara srtuktural (Halim 2016, 101). Asas Kurikulum pendidikan Agama Islam berarti pondasi yang dijadikan sebagai dasar dirancangnya suatu materi, program kegiatan, proses 
1124 Impelementasi Asas-asas Pengembangan Kurikulum terhadap Pengembangan Kurikulum Pendidikan Agama Islam - Satria Kharimul Qolbi, Tasman Hamami

DOI: https://doi.org/10.31004/edukatif.v3i4.511

pembelajaran, dan evaluasi serta cakupan lainya yang sesuai landasan ajaran agama Islam. Prinsip dari asas ini bahwa setiap kurikulum yang diterapkan oleh setiap lembaga pendidikan memiliki karakter tersendiri, maka dari itu pondasi yang menjadi dasar kurikulum sangat menentukan arah tujuan pendidikan tersebut. Lembaga pendidikan yang memiliki karakter atau berbentuk pendidikan agama Islam maka pondasi yang tepat dalam menyusun kurikulumnya adalah Al-Qur'an dan As-Sunnah yang menjadi pedoman bagi ajaran agama Islam. Dari dua sumber tersebut akan dikemas sedemikian rupa sehingga tersusunlah materi-materi yang sistematis dan siap digunakan dalam proses pembelajaran.

Seiring berjalannya waktu kurikulum pendidikan agama Islam akan mengalami perubahan-perubahan yang signifikan dilatar belakangi banyak faktor sehingga kurikulum mengalami perkembangan. Perkembangan kurikulum itu sendiri merupakan arah kurikulum dari masa saat ini ke tujuan pendidikan sesuai harapan dengan adanya pengaruh positif dari dalam maupun dari luar guna menjadikan peserta didik mampu untuk menghadapi perkembangan masa depannya, maka dari itu pengambangan kurikulum memiliki sifat adaptif menyesuaikan keadaan, aplikatif sesuai kebutuhan serta antisipatif harus dapat selalu siap guna tujuan jangka pendek maupun jangka panjangnya (Wahab \& Sudarmono, 2021). Perkembangan kurikulum pendidikan Islam dalam pengembangannya tentu memiliki sifat adaptif, aplikatif serta antisipatif sehingga dibutuhkanlah asas-asas sebagai pondasi prinsip perkembangannya.

\section{Asas-Asas Dalam Pengembangan Kurikulum Pendidikan Agama Islam}

Asas-asas kurikulum Pendidikan merupakan dasar disusunnya suatu kurikulum pendidikan. Tentu setiap kurikulum memiliki pondasi sebagai dasar berdirinya kurikulum tersebut. Fungsi dasar atau pondasi memberikan arah tujuan yang akan dicapai serta sebagai landasan untuk berdirinya sesuatu kurikulum pendidikan. Hamalik berpendapat kurikulum sumbernya terdiri dari; pertama, kedudukan pengetahuan sebagai sumber diberikan kepada peserta didik hendaklah diserasikan bidang studi masing-masing, kedua, masyarakat juga bagian sumber dari kurikulum maka lembaga pendidikan sebagai sarana bagi masyarakat berfungsi untuk melanjutkan warisan tradisi budaya serta memberikan solusi pada masyarakat dalam perkembangannya. Dan ketiga, individu juga merupakan objek pendidikan maka sebagai sumber kurikulum disusun dengan tujuan untuk membantu perkembangan anak didik secara optimal (Bahri, 2017). Tiga sumber sebagai pondasi kurikulum pendidikan tersebut sangat berperan besar dalam membentuk peserta didik agar dapat mengembangkan potensinya dengan sekolah sebagai agen masyrakat sehingga ketika proses pembelajaran di sekolah telah selesai peserta didik siap berperan di masyarakat dan bangsanya.

Sumber kurikulum di atas memiliki kesamaan dengan pandangan Ronald Doll, yang mengemukakan bahwa dasar kurikulum salah satunya adalah filsafat dan sejarah. Menurut Doll bahwa dasar kurikulum terdiri dari empat bagian yakni dasar Psikologi, dasar sosial-budaya,Ilmu pengetahuan dan dasar Filsafat (Hamalik, 2010). Menilik pendapat Nana Syaodih Sukmadinata mengenai landasan perkembangan kurikulum yaitu terdapat empat landasan utama antara lain; landasan psikologis, landasan filosofis, landasan ilmu pengetahuan teknologi dan landasan sosial-budaya (Bahri, 2017). Untuk pengembangan kurikulum pendidikan agama Islam merupakan proses pembelajaran yang dijalani peserta didik dengan rangkaian kegiatan yang sudah disusun menyempurnakan materi pokok dari materi sebelumnya sesuai prinsip ajaran agama Islam. Hal tersebut juga sebagai upaya dalam memprogramkan pengembangan potensi peserta didik melalui pengalaman belajar yang potensial untuk mencapai visi, misi, tujuan pendidikan agama Islam (Firman Sidik, 2016). Dalam hal ini pengembangan kurikulum pendidikan agama Islam perlu adanya landasan dan pondasi yang kuat agar terjaga karakteristik dari kurikulum tersebut, sehingga sangat diperlukan kerjasama terstruktur dari guru, peserta didik, wali serta pihak yang terkait.

Mengenai asas-asas perkembangan kurikulum pendidikan agama Islam maka yang menjadi pondasi bagi perkembangannya pertama asas teologi yaitu landasan atau dasar yang menjadi tumpuan berfikir atau berpendapat dalam menyusun suatu rangkaian berdasarkan nilai-nilai ajaran agama. Asas teologi Islam berarti 
1125 Impelementasi Asas-asas Pengembangan Kurikulum terhadap Pengembangan Kurikulum Pendidikan Agama Islam - Satria Kharimul Qolbi, Tasman Hamami

DOI: https://doi.org/10.31004/edukatif.v3i4.511

landasan yang menjadi tumpuan adalah ajaran agama Islam yang bersumber dari Al-Qur'an dan As-Sunnah. Dalam bahasa Yunani, kata "teologi" dibagi menjadi dua kata, yaitu "teologi" mengacu pada Tuhan, dan logika mengacu pada kata-kata atau kata-kata. Oleh karena itu, jika digabungkan secara singkat, makna teologi adalah segala ilmu yang berhubungan dengan Tuhan. Secara sastra, teologi berkaitan dengan teori dan penelitian, sedangkan dalam praktiknya berkaitan dengan doktrin atau doktrin agama tertentu. (Fauzulhaq, 2017).

Agama ditetapkan berlandaskan Al-Qur'an maupun As-Sunnah dengan ajaran nilai-nilai Ilahi, kedua kitab tersebut bersifat umum, abadi dan berlaku sepanjang zaman kedepan. Selain dua sumber tersebut tentu dalam pendidikan Islam memiliki sumber lain yaitu ijtihad, hasil keputusan para ulama. Dalam ijtihad berbentuk 'ijma, qiyas, istihsan, istihsab, dan 'urf (Didiyanto, 2017). Dasar agama hendaknya memiliki posisi tertinggi dalam kurikulum pendidikan khususnya agama Islam, karena kurikulum pendidikan Islam pasti memiliki tujuan yang sejalan dengan ajaran agama Islamrikut An-Nahl: 64 menerangkan.

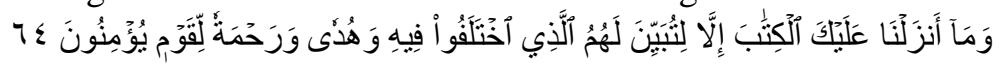

"Dan Kami tidak menurunkan kepadamu Al-Kitab (Al Quran) ini, melainkan agar kamu dapat menjelaskan kepada mereka apa yang mereka perselisihkan itu dan menjadi petunjuk dan rahmat bagi kaum yang beriman"(64).

Al-Qur'an menjadi tempat terdepan dalam pengambilan sumber-sumber pendidikan. Segala bentuk kegiatan konsep pendidikan haruslah berprinsip kepada Al-Qur'an. Terdapat beberapa hal yang berguna dalam Al-Qur'an untu pengembangan pendidikan antara lain: pengembangan ilmiah, penghormatan kepada akal manusia, memelihara kebutuhan manusia serta tidak menentang fitrah manusia (M. Akmansyah, 2015). Sudah sepatutnya landasan utama kurikulum pendidikan agama Islam adalah Teologi atau Tauhid. Nilai-nilai dari ajarana agama Islam bersumber dari Kitab Al-Qur'an dan As-Sunnah serta beberapa pandangan tafsir yang dapat menjadi rujukan yang sesuai dengan prinsip pendidikan di Indonesia. Tentunya aspek tauhid sebagai landasan utama menekankan bahwa dalam kurikulum pendidikan Islam penanaman Aqidah sangatlah kuat. Setelah itu baru pembiasan ibadah dan perilaku Akhlak yang mulia.

Kedua Asas Filosofis yaitu landasan yang menjadi tumpuan dalam berfikir dan menyusun suatu rangkaian berdasarkan penyelidikan mengenai hakikat yang ada sebabnya, asal usulnya serta hukumnya sehingga ditemukannya suatu keputusan yang bijak. Manusia yang belajar filsafat menjadikan manusia tersebut mengerti dan bertindak secara bijak. Untuk menjadi manusia bijak sebagai manusia perlu adanya pengetahuan tentang itu melalui sistematika berfikir logis dan mendalam. Arti lain pemikiran tersebut dapat diartikan sebagai berfikir sampai ke akar-akarnya (Winarso, 2015). Dalam filsafat terdapat aliran yang memiliki latar belakang dan konsep yang berbeda. Usaha menyatukan konsepsi idealisme dan realisme dalam pertentangannya merupakan tujuan dari Aliran essensialisme. Aliran yang bersifat "progresif" yaitu mengembalikan budaya lalu sampai abad pertengahan ke masa saat ini yakni aliran perennialisme. Aliran yang menjadikan kebebasan sebagai pokok utama dan menentang semua bentuk otoriter yaitu Aliran progresifisme. Aliran yang menekankan pada pengalaman individu adalah Aliran eksistensialisme. Berikutnya aliran yang memiliki pandangan bahwa segala gejala bermuara pada keberadaannya, yakni cara manusia berada di dunia berbeda dengan keberadaan benda-benda lainnya yakni aliran rekonstruksionalisme (Bahri, 2017). Dibawah ini dijabarkan tentang isi dari aliran-aliran filsafat yang berkaitan dengan pengembangan kurikulum (Winarso, 2015). Antara lain: 
1126 Impelementasi Asas-asas Pengembangan Kurikulum terhadap Pengembangan Kurikulum Pendidikan Agama Islam - Satria Kharimul Qolbi, Tasman Hamami

DOI: https://doi.org/10.31004/edukatif.v3i4.511

Tabel 1. Aliran-Aliran Filsafat dalam Pengembangan Kurikulm

\begin{tabular}{|c|c|l|}
\hline No & Aliran & \multicolumn{1}{|c|}{ Karakter } \\
\hline 1 & Perenialisme & $\begin{array}{l}\text { Kekekalan, idealisme, dan keindahan berdasarkan silsilah budaya dan } \\
\text { pengaruh masyarakat. Manusia beranggapan bahwa ilmu lebih kritis dan } \\
\text { aktivitas harian yang kurang diperhatikan. Pendidikan yang menganut } \\
\text { ideologi ini mengedepankan kebenaran tidak terbatas, kebenaran umum } \\
\text { yang tidak dibatasi oleh ruang dan waktu. Arus informasi ini lebih } \\
\text { mengedepankan pada masa lampau. }\end{array}$ \\
\hline 2 & Esensialisme & $\begin{array}{l}\text { Pentingnya warisan budaya dan karunia pengetahuan dan keterampilan } \\
\text { bagi siswa untuk menjadi anggota masyarakat yang berguna. Manusia- } \\
\text { manusia beranggapan bahwa berhitung, fisika, dan mata pelajaran } \\
\text { lainnya adalah fondasi konten kurikulum yang berharga bagi kehidupan } \\
\text { masyarakat. Serupa dengan penggunaan perenialisme, esensialisme juga } \\
\text { lebih berpandangan pada masa lalu. }\end{array}$ \\
\hline 3 & Eksistensialisme & $\begin{array}{l}\text { Bahwa individu adalah asal muasal pengetahuan mengenai kehidupan } \\
\text { dan makna. Untuk kehidupan sesemanusia yang dapat dipahami, } \\
\text { sesemanusia harus memahami dirinya sendiri. }\end{array}$ \\
\hline 4 & Progressivisme & $\begin{array}{l}\text { Tingkat menyelesaikan perbedaan dalam pengalaman dan proses belajar } \\
\text { individu, berpusat pada siswa, dan beragam. Progresivisme adalah dasar } \\
\text { untuk pembelajaran dan pengembangan aktif siswa. }\end{array}$ \\
\hline 5 & Rekonstruksionisme & $\begin{array}{l}\text { Penjelasan rinci tingkat tinggi berdasarkan genre progresif. Dalam } \\
\text { rekonstruksionisme, peradaban manusia masa depan sangat ditekankan. } \\
\text { Selain menekankan pada perbedaan individu, misalnya dalam } \\
\text { progresifisme, rekonstruksionisme juga menekankan pada pemecahan } \\
\text { masalah dan pemikiran kritis. Proses ini akan mempertanyakan mengapa } \\
\text { Anda perlu berpikir kritis, memecahkan masalah dan membuat } \\
\text { perbedaan? Pendukung tipe ini menekankan pada hasil pembelajaran } \\
\text { dalam proses }\end{array}$ \\
\hline
\end{tabular}

Dari karakter aliran di atas, maka disesuaikan dalam pengembangan kurikulum, secara filosofis tentunya aliran-aliran filsafat tertentu dapat menjadi acuan dasar dalam kurikulum pendidikan. Hal ini memberikan variasi terhadap konsep rangkaian dan pengembangan implementasinya. Aliran filsafat eksistensialisme, perenialisma, essensialisme yakni aliran yang melandasi pengembangan kurikulum bentuk subjek-akademis yaitu kurikulum yang bersumber dari pendidikan klasik berfokus kepada isi dari pendidikan berupa penekanan materi yang disampaikan guru. Filsafat progresivisme memberikan landasan pengembangan kurikulum bentuk pendidikan pribadi atau humanistic konsep ini lebih mengutamakan pendidikan kepada peserta didik dalam pembelajaranya dan tidak hanya ranah kognitif namun sikap, emosi peserta didik juga ditekankan pada konsep ini. Selanjutnya, filsafat ini banyak diterapkan dalam pengembangan kurikulum yakni rekonstruktivisme dengan model interaksional atau penekanan dalam komunikasi yaitu menciptakan suasana belajar yang interaktif dari dua pihak peserta didik dan guru sehingga terciptanya pembelejaran yang kebih komunikatif (Bahri, 2017).

Ketiga asas psikologi yaitu landasan yang menjadi tumpuan berfikir yang berdasarkan teori-teori psikologi yang berkaitan dengan tingkah laku perilaku manusia serta keadaan latar belakang manusia (Suminto, 2020). Bahwa kondisi psikologi merupakan sesemanusia sebagai individu dengan karakteristik psiko-fisik, yang dinyatakan dalam bentuk perilaku dan berbagai tindakan dalam interaksi dengan lingkungannya (Fauzan et al., 2019). Syafruddin Nurdin berpendapat, bahwa pada landasannya pendidikan memiliki unsur-unsur psikologi yang melatarbelakangi proses pendidikan. Proses pendidikan adalah suatu hal yang berkaitan dengan perilaku manusia itu sendiri serta mendidik berarti memberikan pembelajaran agar ada perubahan dari tingkah laku anak didik mencapai kedewasaannya. Oleh karena itu, dalam proses pemelajaran 
1127 Impelementasi Asas-asas Pengembangan Kurikulum terhadap Pengembangan Kurikulum Pendidikan Agama Islam - Satria Kharimul Qolbi, Tasman Hamami

DOI: https://doi.org/10.31004/edukatif.v3i4.511

sangat berkaitan dengan teori tingkah laku anak. Nana berpendapat Beberapa hal yang berkaitan dengan teori tingkah laku anak antara lain (Bahri, 2017):

Tabel 2. Teori Tingkah Laku Anak

\begin{tabular}{|c|c|c|}
\hline No & Teori & Karakter \\
\hline 1 & Behavioristik & $\begin{array}{l}\text { Teori belajar behavioristik yaitu teori yang membahas tingkah laku manusia } \\
\text { pada proses belajar melalui pendekatan yang sesuai dengan keadaan } \\
\text { sebenarnya, mekanistik memiliki prosedur tersendiri, dan materialistic. } \\
\text { Perubahan tingkah laku melalui upaya pengkondisian dapat terjadi pada diri } \\
\text { manusia dan keadaan masing-masing manusia. Kegiatan behavioristik } \\
\text { dilatarbelakangi bahwa pada saat anak lahir tidak mewarisi keserdasan, } \\
\text { kemampuan dan bakat. Teori behavior lebih menekankan kepada pengamatan } \\
\text { tingkah laku manusia, karena prinsip dari perubahan manusia tentunya harus } \\
\text { dilakukan dengan pengamatan dan pengalaman sehingga dapat disimpulkan } \\
\text { ada tidaknya perubahan tersebut. }\end{array}$ \\
\hline 2 & Psikologi Daya & $\begin{array}{l}\text { Pada teori ini kesiapan mental menjadi dasar dalam perubahan tingkah laku } \\
\text { manusia. Baik dalam proses pembelajaran mental dari daya mengamati, } \\
\text { mengingat, menanggapi, menghayal serta berfikir dimana hal tersebut } \\
\text { diperoleh melalui latihan. Teori ini menekankan pada nilai formal, artinya } \\
\text { setiap materi apapun yang dipelajari sesemanusia tidaklah signifikan apabila } \\
\text { tidak adan pengaruhnya terhadap perubahan daya-daya tertentu. }\end{array}$ \\
\hline 3 & $\begin{array}{l}\text { Perkembangan } \\
\text { Kognitif }\end{array}$ & $\begin{array}{l}\text { Teori ini mengutamakan proses atau upaya guna memaksimalkan kecakapan } \\
\text { rasional yang dimiliki setiap manusia. Terdapat perbedaan kognitif dengan } \\
\text { behavioristic, yang lebih menekankan pada aspek kemampuan perilaku. } \\
\text { Piaget memiliki pandangan bahwa perkembangan kognitif merupakan suatu } \\
\text { proses genetic, yaitu proses yang didasarkan atas mekanisme biologis } \\
\text { perkembangan system syaraf manusia. }\end{array}$ \\
\hline 4 & Teori Gestalt & $\begin{array}{l}\text { Teori ini menekankan pada kita bahwa dalam perkembangan haruslah } \\
\text { melihat secara keseluruhan. Dengan melihat secara keseluruhan maka dapat } \\
\text { ditemukanlah solusi yang tepat. Contoh dalam melihat permasalahan } \\
\text { pendidikan pada masyarakat multi kultur tentu teori ini sangat tepat dalam } \\
\text { mencari solusi. Masyarakat multikultur dengan kultur yang berbeda-beda } \\
\text { perlu ditinjau dan dipelajari secara keselurah. Setelah itu akan ditemukan dari } \\
\text { berbagai perbedaan cara yang tepat dalam memberikan formula system } \\
\text { pendidikan yang tepat }\end{array}$ \\
\hline 5 & $\begin{array}{c}\text { Teori } \\
\text { Kepribadian }\end{array}$ & $\begin{array}{l}\text { 1) berdasarkan Hilgard \& Marquis kepribadian ialah nilai rangasangan sosial, } \\
\text { potensi buat menampilkan diri secara mengesankan, 2) berdasarkan Stern } \\
\text { kepribadian artinya kehidupan semanusia secara keseluruhan, individual, } \\
\text { unik, kemampuannya bertahan, serta memperoleh pengalaman, 3) dari } \\
\text { Allport kepribadian merupakan organisasi dinamik yg berubah-ubah dalam } \\
\text { sistem psikofisiologik berkaitan mental dan perilaku sesemanusia pada } \\
\text { memilih contoh penyesuaiannya yang unik dengan lingkungannya, 4) } \\
\text { berdasarkan Guilford kepribadian merupakan sifat yang unik pada diri } \\
\text { sesmanusia. 5) dari Pervin kepribadian ialah ciri semanusia yang menyeluruh } \\
\text { sehingga mengakibatkan pola menetap dalam merespon suatu situasi, 6) } \\
\text { menurut Maddy atau Burt bahwa kepribadian adalahkarakteristik tersusun } \\
\text { dan stabil, yang menentukan keumuman dan perbedaan tingkah laku } \\
\text { psikologi dalam waktu yang lama dan tidak dapat dipahami secara sederhana } \\
\text { sebagai hasil dari tekanan sosial dan tekanan biologik saat itu (Muhimmatul } \\
\text { Hasanah, 2015). }\end{array}$ \\
\hline
\end{tabular}

Uraian diatas menunjukan bahwa asas psgikologi terdapat keutaman besar dalam pengembangan kurikulum pendidikan. Anak berupa target kurikulum dalam implementasinya pada pendidikan tentunya memerlukan landasan psikologi sehingga masa perkembangan anak dalam menempuh proses pendidikan 
1128 Impelementasi Asas-asas Pengembangan Kurikulum terhadap Pengembangan Kurikulum Pendidikan Agama Islam - Satria Kharimul Qolbi, Tasman Hamami

DOI: https://doi.org/10.31004/edukatif.v3i4.511

sudah memiliki formula yang tepat dalam rangkaian kurikulum yang sudah ditetapkan. Masa perkembangan anak banyak ditelaah dalam ilmu Psikologi hal tersebutlah yang mendasari psikologi sebagai bagian dari Asas Kurikulum.

Keempat, asas sosial-budaya yaitu landasan yang menjadi tumpuan berfikir yang berdasarkan kepentingan nilai-nilai masyarakat serta norma-norma tradisi yang melekat pada masyarakat. Sosial-budaya yang terdapat nilai-milai masyarakat bersumber dari manusia dengan karyanya melalui nalar akal budinya sehingga dalam melestarikan dan menyebarluaskannya. Pada pendidikan juga terdapat proses interaksi antara manusia sehingga menjadikan manusia sebagai makhluk yang berbudaya. Pada konteks ini peserta didik berada di fenomena budayanya, diharapkan siswa bisa dibina serta dikembangakan sinkron dengan nilai budayanya. Kebudayaan yang diharapkan siswa merupakan budaya yang positif memiliki efek baik bermanfaat bagi insan dan warga (Halim, 2016). Asas sosial budaya sebagai landasan kurikulum pendidikan tentuanya berperan besar dalam mendasari bagaimana kurikulum tersebut dapat diimplementasikan peserta didik kepada masyarakat. Fakta bahwa terdapat beragam budaya tentunya mempengaruhi konsep kurikulum pendidikan. Aspek terpenting dalam sosial budaya adalah system nilai yang mengatur kehidupan bermasyarakat, maka dari itu pada kurikulum pendidikan dengan asas sosial budaya menjadi solusi untuk merangkai kurikulum yang tepat agar setiap perbedaan budaya dapat dilakasanakan peserta didik dengan baik sehingga tercapainya pendidikan yang sesuai kondisi sosial budaya khususnya di Indonesia.

Asas ini menggambarkan kurikulum pendidikan agama Islam diserasikan pada nilai-nilai sosial yang berciri khas masyarakat Islam serta kebudayaannya. Hal ini terdiri dari sisi etika, pengetahuan, pola pikir, dan tradisi adat istiadat masyarakat sesuai cirikhas kebudayaannya. Kurikulum pendidikan agama Islam harus berkesinambungan dengan perkembangan yang ada pada masyarakat (Firman Sidik, 2016). Asas sosialbudaya bagi kurikulum pendidikan agama Islam akan menghasilkan produk yang sesuai dengan kebutuhan masyarakat. Khususnya Indonesia yang memiliki keragaman budaya dan tradisi tentu akan mempengaruhi proses pendidikan kedepannya. Ditambah lagi faktor geografis di Indonesia juga memperlihatkan betapa banyaknya budaya yang berbeda di setiap tempatnya. Asas sosial bagi kurikulum pendidikan agama Islam diharapakan dapat memberikan formula yang tepat bagi peserta didik dalam menjalai proses pendidikan sehingga nilai-nilai sosial seperti toleransi, gotong royong dan interkasi sosial berjalan dengan baik.

Kelima, asas ilmu pengetahuan dan teknologi yaitu landasan yang menjadi tumpuan berfikir yang berdasarkan kumpulan gagasan atau penemuan yang sudah dilalui berbagai proses ilmiah sehingga menghasilkan suatu produk baik barang atau pedoman yang dapat menjadi sumber pengembangan ilmu lainnya serta sebagai alat yang memudahkan manusia dalam memenuhi kebutuhan sehari-hari. Produk IPTEK beraneka ragam dan sifatnya dinamis, seiring berkembangnya zaman kemajuan IPTEK sangat mempengaruhi perannya dalam kehidupan manusia sehingga IPTEK berpengaruh sabagai landasan kurikulum pendidikan. Teknologi pada dasarnya merupakan peran hasil ilmu pengetahuan serta memiliki kedudukan yang sangat signifikan dalam perkembangan manusia. Karya dari manusia melahirkan teknologi melalui proses ilmiah agar tercapainya tujuan kehidupan manusia yang paling baik. Sarana manusia untuk lebih mudah menyediakan dan memenuhi kebutuhan juga arti dari Teknologi. Tujuannya adalah untuk membuat keadaan yang efisien, efektif, dan berkaitan kepada corak tindak perilaku manusia. Salah satu indikasi kemajuan peradaban manusia adalah kemajuan IPTEK. Teknologi memiliki kontribusi dalam semua aspek kehidupan manusia. Teknologi tentunya berperan besar memudahkan dalam mengembangkan sumber daya alam yang ada bagi manusia, akan tetapi sering kali melampaui batas tanpa dilakukan dengan bijak sehingga sering terjadi tidak beraturan dalam penggunaannya (Camelia, 2020).

Pengetahuan berasal dari akar kata "ilm" yang artinya lambang atau penunjuk agar dapat dikenali dan diketahui. Sama halnya dengan ma'lam, artinya rambu jalan agar sesemanusia bisa menuntun diri sendiri atau sesemanusia. Selain itu, "Alam juga diartikan sebagai pedoman (Abidin, 2016). Ilmu dapat diartikan sebagai arah mata angin, dimana mata angin memudahkan manusia untuk mencapai tujuan dalam berpergian. 
1129 Impelementasi Asas-asas Pengembangan Kurikulum terhadap Pengembangan Kurikulum Pendidikan Agama Islam - Satria Kharimul Qolbi, Tasman Hamami

DOI: https://doi.org/10.31004/edukatif.v3i4.511

Begitu juga ilmu bagi manusia dengan ilmu manusia dapat mengembangkan potensiya sesuai bidang ilmu masing-masing. Ilmu seringkali disamakan dengan istilah sains dan pengetahuan yang dijajarkan menjadi ilmu pengetahuan. Ilmu adalah kesadaran mengenai pengetahuan yang berfungsi untuk menyelediki dan menelaah suatu temuan sementara. Ilmu juga dimaknai pengetahuan yang dihasilkan dengan proses pembelajaran dari pengalaman yang ditempuh. Dalam arti lain ilmu adalah hasil dari pengetahuan yang telah melalui tahap pengujian kebenarannya. Adapun pengetahuan masih dalam sebatas informasi yang sesemanusia ketahui. Memperoleh pengetahuan dapat dengan cara pengalaman yang didapat serta manusia-manusia dengan informasi yang diberikan. Namun dalam hal ini tidak dapat disebut ilmu jika pengetahuan belum teruji kebenarannya (Camelia, 2020). Dari makna tersebut dapat diketahui bahwa ilmu pengetahuan merupakan proses atau upaya dalam penemuan baru dengan berbagai bentuk cara seperti penelitian, eksperiman dan observasi sehingga ditemukanlah teori baru yang disepakati bersama.

\section{Implementasi Asas-Asas Dalam Pengembangan Kurikulum Pai}

Dari berbagai teori asas-asas pengembangan kurikulum diatas maka dapat diterapkan untuk digunakan dalam pengembangan kurikulum pendidikan agama Islam. Jika kita melihat fakta yang ada pada "Keputusan Menteri Agama Nomor 183 Tahun 2019 tentang Kurikulum PAI dan Bahasa Arab pada Madrasah" terdapat empat asas yang digunakan sebagai pondasi yaitu asas filosofis, sosiologis, psikopedagogis dan yuridis (Direktorat, 2019). Dalam penulisan ini dapat menjadi tambahan usulan kontribusi bagi pengembangan kurikulum pendidikan agama Islam yang dapat diterapkan oleh setiap instansi pendidikan yang ada di Indonesia. Pada keputusan menteri agama tersebut ditinaju dari asas filosofis menerangkan fungsi pentingnya PAI, guru, murid dan bahasa arab dalam kurikulum. Asas sosiologis mengutarakan kurikulum yang sesuai kebutuhan masyarakat. Asas psikopedagogis menerangkan bahwa proses PAI dan bahasa Arab sebagai proses pendewasaan peserta didik. Asas yuridis atau teoritik kurikulum dirancang berdasarkan Pendidikan berbasis standar menetapkan adanya standar nasional sebagai kualitas minimal warga negara yang dirinci menjadi standar isi, standar proses, standar kompetensi lulusan, standar pendidik dan tenaga kependidikan, standar sarana dan prasarana, standar pengelolaan, standar pembiayaan, dan standar penilaian pendidikan.

Uraian tersebut menjadi bahan dalam melengkapi landasan perkembangan kurikulum PAI yang sudah berlaku. Teori yang dikemukakan peneliti terdapat lima asas yang dapat dimanifestasikan kedalam keputusan menteri agama tentang kurikulum PAI dan bahasa Arab dengan rincian sebagai berikut:

Tabel 3. Asas tentang kurikulum PAI dan Bahasa Arab

\begin{tabular}{|c|c|c|}
\hline No & Asas-asas & Penerapannya \\
\hline 1 & Asas Teologi & $\begin{array}{l}>\text { Memunculkan ayat-ayat Al-Qur'an dan beberapa Al-Hadits sebagai pondasi } \\
\text { disusunnya suatu kurikulum } \\
>\text { QS An-Nahl: } 64 \text { yang menjelaskan kedudukan Al-Qur'an sebagai sumber } \\
\text { pendidikan } \\
>\text { QS Al-Alaq:1-5 mekanisme dalam menuntut ilmu } \\
>\text { QS Al-Hasr: } 18 \text { penting pengembangan } \\
>\text { Hadits riwayat sunan al-Tirmidzi no } 2649 \text { mengenai manfaat menuntut ilmu }\end{array}$ \\
\hline 2 & Asas Filosofis & $\begin{array}{l}\text { Secara filosofis beberapa aliran dapat digunakan pada setiap pengembangan } \\
\text { kurikulum: } \\
\text { Subjek-Akademis } \\
\text { Humanistik atau kepribadian } \\
\text { Ketika landasan tersebut dapat dijadikan satu dalam penerapannya sehingga } \\
\text { terdapat perpaduan }\end{array}$ \\
\hline 3 & Asas & $>$ Behavioristik: bahwa pendidikan dilalui melalui proses jenjang yang \\
\hline
\end{tabular}


1130 Impelementasi Asas-asas Pengembangan Kurikulum terhadap Pengembangan Kurikulum Pendidikan Agama Islam - Satria Kharimul Qolbi, Tasman Hamami

DOI: https://doi.org/10.31004/edukatif.v3i4.511

\begin{tabular}{|c|c|c|}
\hline & Psikologi & $\begin{array}{l}\text { berbeda, sehingga perlu adanya penerapan yang sesui dengan jenjangnya } \\
\text { seperti kasus pada peserta didik jenjang dasar pada pembelajaran PAI masih } \\
\text { banyak peserta didik yang belum menguasai Al-Qur'an sehingga kesulitan } \\
\text { dalam mengikuti proses belajar maka teori ini dapat menjadi solusi untuk } \\
\text { mengidentifikasi materi yang sesuai jenjangnya } \\
>\text { Psikologi daya: guna membentuk kemandirian pada peserta didik, hendak } \\
\text { proses belajar tidak dominan pada guru melainkan pada siswa yang belajar } \\
\text { mandiri shingga dapat dibentuk berupa metode berlandaskan Mandiri } \\
\text { Belajar } \\
\text { Teori kognitif: dengan adanya peningkatan pengetahuan berupak tingkat } \\
\text { kelas, tingkat kesulitas materi dan kelas akselerasi maka atas landasan } \\
\text { tersebut peserta didik diberikan transfer ilmu sesuai dengan kemapuan } \\
\text { potensinya } \\
\text { Teori gestalt: pengembangan ilmu tidak hanya focus pada satu acuan } \\
\text { melainkan keselurahan yang berkaitan dengan ilmu tersebut sehingga hal ini } \\
\text { mengharuskan kurikulum memiliki landasan psikologi dengan teori tersebut } \\
\text { Teori kepribadian: pengembangan kurikulum bertujuan membantuk } \\
\text { kepribadian yang baik sehingga peserta didik menjadi manusia yang dewasa } \\
\text { serta bijak mengambil keputusan }\end{array}$ \\
\hline 4 & $\begin{array}{l}\text { Asas Sosial- } \\
\text { Budaya }\end{array}$ & $\begin{array}{l}\text { Selain menyesuaikan kebutuhan masyarak yang terpenting adalah } \\
\text { pengenalan budaya seperti menggunakan atribut budaya pada masing-masing } \\
\text { khas daerah tersebut pada proses pendidikan } \\
>\text { Pembelajaran PAI dapat berkegiatan ke taman budaya pada masing-masing } \\
\text { daerah } \\
>\text { Study banding yang sudah berjalan itu sangatlah baik dalam pengenalan } \\
\text { budaya } \\
\text { Terjalinnya komunikasi antar masyaraka-pendidik-orang tua-sekolah-peserta } \\
\text { didik akan menciptakan korelasi yang baik dalam menanamkan norma- } \\
\text { norma sosial bagi peserta didik }\end{array}$ \\
\hline 5 & $\begin{array}{l}\text { Asas Ilmu } \\
\text { Pengetahuan } \\
\text { dan Teknologi }\end{array}$ & $\begin{array}{l}\text { Menciptakan suatu karya ilmiah pada setiap jenjang yang sesuai dengan } \\
\text { kemampuannya } \\
>\text { Strategi metode belajar dengan memaksimalkan teknologi yang berkembang } \\
>\text { Media-media belajar mengunakan digitalisasi } \\
>\text { Standarisasi penggunaan teknologi pada setiap instasn pendidikan yang ada } \\
\text { di Negara ini }\end{array}$ \\
\hline
\end{tabular}

Paparan diatas dapat menjadi suatu landasan bagi pengembangan kurikulum pendidikan agama Islam dalam penyusunan kurikulum PAI yang dapat distandarkan pada semua lembaga pendidikan baik dari jenjang dasar maupun jenjang tinggi. Dalam penulisan ini pada dasarnya masih terdapat keterbatasan dalam meninjau ayat-ayat Al-Qur'an dan Al-Hadits dijadikan sebagai pondasi teologi dalam pengembangan kurikulum. Pada prinsipnya kedua pedoman tersebutlah yang menjadi sumber pokok utama pondasi dalam pengembangan kurikulum pendidikan agama Islam secara teologi sehingga arah tujuan pencapaianya jelas tuntutannya. Akan tetapi dengan tinjauan teori asas-asas diatas dapat menjadi kontribusi dalam menerapkan perkembangan ilmu pengetahuan dan teknologi dalam pengembangan kurikulum PAI sehingga sekolah, pendidik, serta peserta didik dapat tanggap teknologi.

Keputusan Menteri Agama Nomor 183 Tahun 2019 tentang Kurikulum PAI dan Bahasa Arab pada Madrasah belum ada asas teologi dan asas ilmu pengetahuan dan teknologi, maka dari itu dengan adanya penelitian ini menjadi pelengkap secara teoritis implementasi asas-asas tersebut dapat menjadi landasan yang ada pada keputusan menteri agama dan secara praktis berupa penerapan teknologi pada proses belajar yang berwujud materi-materi PAI yang berkolaborasi dengan pengembangan teknologi sehingga semua komponen yang berkaitan dengan kegiatan pembelajaran memiliki karakter tanggap teknologi. 
1131 Impelementasi Asas-asas Pengembangan Kurikulum terhadap Pengembangan Kurikulum Pendidikan Agama Islam - Satria Kharimul Qolbi, Tasman Hamami

DOI: https://doi.org/10.31004/edukatif.v3i4.511

\section{KESIMPULAN}

Dari hasil penulisan ini dapat disimpulkan bahwa terdapat lima asas yang dapat menjadi pondasi dalam pengembangan kurikulum pendidikan agama Islam terdiri dari asas teologi, asas filosofis, asas psikologi, asas sosial-budaya serta asas ilmu pengetahuan dan teknologi. Implementasi asas tersebeut dalam pengembangan kurikulum pendidikan agama Islam secara teoritis dan praktis dapat menjadi acuan bagi pihak wewenan dalam mengembangkan kurikulum pendidikan agama Islam dari asas teologi menggunakan dua sumber pokok $\mathrm{Al}$ Qur'an dan Al-Hadits, asas filosofis menggunakan konsep aliran dalam mekanisme proses pembelajaran, asas psikologi mengidentifikasi kemampuan peserta didik sesuai jenjang dan potensinya, asas sosial-budaya menggunakan atribut budaya dalam pengenalannya, asas ilmu pengetahuan dan teknologi memaksimalkan perkembangan teknologi dengan proses pembelajaran. Hal-hal tersebut dapat menjadikan kurikulum pendidikan agama Islam dapat diimplikaskan semua komponen pendidikan saat ini dan seterusnya.

\section{DAFTAR PUSTAKA}

Abidin, M. Z. (2016). Konsep Ilmu Dalam Islam: Tinjauan Terhadap Makna, Hakikat, Dan Sumber-Sumber Ilmu Dalam Islam. Jurnal Ilmiah Ilmu Ushuluddin, Vol. 10(No.1)

Bahri, S. (2017). Pengembangan Kurikulum Dasar Dan Tujuannya. Jurnal Ilmiah Islam Futura, Vol. 11(1)

Camelia, F. (2020). Analisis Landasan Ilmu Pengetahuan Dan Teknologi. SAP (Susunan Artikel Pendidikan), Vol. 5(No. 1)

Didiyanto, D. (2017). Paradigma Pengembangan Kurikulum Pai Di Lembaga Pendidikan. Edureligia; Jurnal Pendidikan Agama Islam, Vol. 1(No. 2),

Direktorat, T. D. K. M. (2019). Keputusan Menteri Agama Tentang Kurikulum PAI dan Bahasa Arab.

Fauzan, F., Lateh, A., \& Arifin, F. (2019). Analisis Kurikulum Pendidikan Agama Islam di Indonesia dan Thailand (Studi kebijakan Kurikulum 2013 dan Kurikulum 2008 di tingkat SMA). Edukasia: Jurnal Penelitian Pendidikan Islam, 14(2)

Fauzulhaq, M. H. (2017). Konsep Teologi Dalam Perspektif Seren Taun Di Kesepuhan Cipta Mulya. Jurnal Aqidah Dan Filsafat Islam, 2(1)

Firman Sidik. (2016). Konsep Pengembangan Kurikulum Pendidikan Islam. Irfani, Vol. 12(No. 1)

Halim, A. (2016). Asas-Asas Pengembangan Kurikulum Pendidikan Islam Multikultural. Nidhomul Haq, Vol. 1(No. 2)

Hamalik, O. (2010). Manajemen Pengembangan Kuri. Remaja Rosdakarya.

Hermawan, Y. C., Juliani, W. I., \& Widodo, H. (2020). Konsep Kurikulum Dan Kurikulum Pendidikan Islam. Jurnal MUDARRISUNA: Media Kajian Pendidikan Agama Islam, 10(1), 34 https://doi.org/10.22373/jm.v10i1.4720

Irsad, M. (2016). PENGEMBANGAN KURIKULUM PENDIDIKAN AGAMA ISLAM DI MADRASAH (Studi Atas Pemikiran Muhaimin)

M. Akmansyah. (2015). Al-Qur'an dan As-Sunnah sebagai Dasar Ideal Pendidikan Islam. Pengembangan Masyarakat Islam, 8(2)

Muhimmatul Hasanah. (2015). Dinamika Kepribadian Menurut Psikologi Islami. Ummul Quro, Vol. 6(No. 2)

Mustika, Z. (2008). Metode Penelitian Kepustakaan. Yayasan Obor Indonesia.

Noorzanah. (2018). Kurikulum Dalam Pendidikan Islam. Ittihad Jurnal Kopertais Wilayah XI Kalimantan, 
1132 Impelementasi Asas-asas Pengembangan Kurikulum terhadap Pengembangan Kurikulum Pendidikan Agama Islam - Satria Kharimul Qolbi, Tasman Hamami

DOI: https://doi.org/10.31004/edukatif.v3i4.511

Vol.15(No.28)

Nurhalita, N. (2021). EDUKATIF: JURNAL ILMU PENDIDIKAN Relevansi Pemikiran Pendidikan Ki Hajar Dewantara pada Abad ke 21 Abstrak. Edukatif: Jurnal Ilmu Pendidikan, Vol. 3(No. 2)

Rahmat Hidayat. (2016). Ilmu Pendidikan Islam. LPPPI.

Sanjaya, W. (2010). Strategi Pembelajaran Berorientasi Standar Proses Pendidikan. Kencana.

Suminto. (2020). Asas Psikologi dan Implikasinya dalam Pendidikan Islam Perspektif Hasan Langlung. Andragogi: Jurnal Ilmiah Pendidikan Agama Ilslam, Vol. 2(No. 1), 1-14.

Wahab, A., \& Sudarmono, M. A. (2021). Proses dan Prinsip Pengembangan Kurikulum Pendidikan Guru Madrasah Ibtidaiyah. Edukatif: Jurnal Ilmu Pendidikan, Vol. 3(No. 2), 278-287.

Winarso, W. (2015). Dasar Pengembangan Sekolah.

Yeni Tri Nur Tahmawati, S. (2018). Islamic Akademika : Jurnal Pendidikan \& Keislaman. Jurnal Pendidikan \& Keislaman, 3(1), 77-87. 